\title{
The Effects of Tasks on Language-Related Episodes (LREs) During Focus-on-Form Instruction
}

\author{
Lilliati Ismail \\ Sekolah Agama Menengah Hulu Langat, Malaysia \\ lilliati75@yahoo.com \\ Arshad Abd. Samad \\ Universiti Putra Malaysia, Malaysia \\ arshad@educ.upm.edu.my
}

\begin{abstract}
This paper discusses the effectiveness of using two task-types, dictogloss and opinion-gap tasks, in focus-on-form lessons to elicit language-related episodes (LREs) and produce modified output. The participants were 40 Form 6 students in a Malaysian secondary school in two intact classes. One group was taught using opinion-gap tasks and the other using dictogloss tasks. Results show that almost double the number of LREs was elicited in the dictogloss group compared to the opinion-gap group. However, more than $50 \%$ of the LREs in both groups were unresolved or wrongly resolved. These results imply the need to train learners to notice linguistic errors and engage in negotiations of form and meaning and could also indicate the need for teacher feedback on language use, perhaps during pre-task and post-task activities. The types of linguistic errors learners focused on might be an indication of learner developmental readiness which could influence task and text selection.
\end{abstract}

With the current inclination in second language acquisition (SLA) practices toward task-based language teaching (TBLT), there is a growing concern that the importance of language accuracy will be undermined. Skehan and Foster (2001), for example, argue that a task-based approach, if inappropriately handled, could result in an overemphasis on task outcomes at the expense of improving target language ability. As a result, it could encourage premature fossilization rather than promote interlanguage development. Thus, SLA researchers (e.g., Ellis, 2001; Ellis, Basturkmen, \& Loewen, 2001; Loewen, 2004; Leeman, 2007) have argued for the need to incorporate grammar instruction in a meaning-focused lesson. These researchers challenge Krashen's (1985) input hypothesis, which posits that grammar instruction is not an important part of language instruction. Instead, he contends that language is developed through massive comprehensible input of the language. Initially, Long (1985), through the interaction hypothesis, concurred that comprehensible input facilitates acquisition as it provides opportunities to negotiate meaning during a communicative breakdown. Later, Long (1996) extended his hypothesis to include feedback and modified output as important contributors to interlanguage development. He explains that the feedback learners receive on their language production when they attempt to communicate could contribute to language acquisition, as this would push learners to reformulate their productions to make them comprehensible.

Language Education in Asia, 2010, 1(1), 87-98. http://dx.doi.org/10.5746/LEiA/10/V1/A08/Ismail_Samad 
Long (1991) coined the term focus-on-form to refer to lessons with communicative activities and tasks as the core focus, but these lessons are interrupted by focus on linguistic problems as and when it is necessary to aid communication. He distinguishes between focus-on-form and focus-on-formS. A focus-on-form lesson would focus on communication, while language forms (e.g., grammar, vocabulary, pronunciation) are dealt with as and when the need arises in the course of meaning-making. On the other hand, a focus-on-formS lesson would have language forms as the central focus. For instance, a typical P-P-P lesson, with grammar presentation, practice, and production would fall under the focus-on-formS category.

Long and Robinson (1998) summarise the three options of second language (L2) instruction with focus-on-form as a middle option on the focus-on-formS and focus on meaning continuum, as shown in Figure 1 below:

focus on meaning

- Natural Approach

- Immersion

- Procedural syllabus focus-on-form

- Task-Based Language Teaching (TBLT)
focus-on-formS

- Audio-lingual Method (ALM)

- Grammar Translation (GT)

- Total Physical Response (TPR)

- Structural syllabus

Figure 1. Options in language teaching. Adapted from Long and Robinson (1998).

Though focus-on-formS instruction appears to facilitate learning as measured by discrete-point language tests, there is little evidence to show that it results in increased accuracy during oral communication. For example, a meta-analysis study conducted by Norris and Ortega (2000), in which they reviewed 49 studies, mainly of the focus-on-formS kind, found that the effectiveness of the instruction was markedly reduced when it was measured in terms of learners' ability to use targeted structure spontaneously in communication.

On the other hand, a pure focus on meaning during lessons, as advocated by Prabhu (1987) in his procedural syllabus, has been deemed insufficient for L2 learning beyond the critical period. This is in line with Lenneberg's (1967) critical period hypothesis, which stipulates that children who are L2 learners would acquire the target language to a native-like level given the appropriate exposure to the language. However, adults would not achieve native-like levels of the L2 as they have passed the developmental, or critical, period.

The shortcomings of focus-on-formS instruction and purely communicative lessons, as proven by theory and empirical research, have led some researchers (e.g., Long, 1991; Ellis et al., 2001, 2002; Loewen, 2004) to suggest that an approach based on focus-on-form would work better in facilitating second language acquisition.

The current study used tasks as the organizing principle, as SLA researchers have recognized the potential of task-based instruction to create more opportunities to negotiate meaning than traditional instruction (e.g., Long, 1985, 1991; Robinson, 2001). DeKeyser (2001) also points out that task-based language teaching is particularly useful in facilitating the development of accuracy in language production. Pica (1994) highlights that communication tasks allow for comprehension, feedback, and modified output. For the current study, two task-types dictogloss and opinion-gap - were used as they have differing cognitive demands. A dictogloss task (Wajnryb, 1990) consists of a series of stages. First, learners listen to a short, dense passage during which they are instructed to listen only and not write anything down. Secondly, they 
listen to the passage a second time and may jot down notes. Thirdly, when working in pairs or small groups, learners pool their notes together and attempt to reconstruct their own written version of the passage. Finally, each group presents their passage to the class. The opinion-gap task requires students to give their opinions based on given topics. First, they jot down their own ideas. Then, they discuss their opinions in small groups. Finally, each group presents their collective opinion which has been written in one paragraph.

\section{Theoretical Background}

The focus on comprehensible modified output is in line with Swain's (1995) comprehensible output hypothesis. According to Swain (1995), output serves three main functions. It prompts learners to test hypotheses, allows learners to notice gaps in language use, and acts as a springboard for metalinguistic awareness. The idea of bringing learners' attention to gaps in their language use is what is termed as "noticing" (Schmidt, 1990). Through his noticing hypothesis, Schmidt (1990) argues that noticing would facilitate learning and "those who notice most learn most, and it may be that those who notice most are those who pay attention most, as a general disposition or on particular occasions" (p. 144). The comprehensible output hypothesis and noticing hypothesis have laid the foundation for focus-on-form instruction.

A variable manipulated in the study is task complexity. Task complexity is closely related to the information processing demand and cognitive load a learner deals with in the course of completing a task (Robinson, 2001). Ishikawa (2006) states that task complexity can be viewed as the task's inherent information processing demands that can be graded, sequenced, and manipulated by the teacher. Robinson (2001), through his cognition hypothesis, argues that increasing the cognitive demands of L2 tasks will lead to greater attention to output, heightened noticing, and greater processing of input. As a result, interlanguage development is accelerated, as there is ample opportunity to notice and attend to linguistic gaps.

Contrary to Robinson's cognition hypothesis, Skehan (1998), through his limited capacity model, takes Van Patten's (1990) stance that learners would lose attention to form when they have to deal largely with content. Skehan (1998) argues that human beings have a limited capacity to process information. As a result, task content and language accuracy are in competition with each other for a learner's attention. Thus, more complex tasks will demand more attention on content, resulting in less attention given to language use. In the case of the current study, the opinion-gap task, which is more cognitively demanding than the dictogloss task, is expected to result in more attention given to content, thus adversely affecting language repair.

\section{Language-Related Episodes (LREs) / Metatalk}

Language-Related Episodes (LREs) are segments of learner interaction in which learners either talk about or question their own or others' language use within the context of carrying out a given task in the L2 (Swain, 1998; Swain \& Lapkin, 2001). Swain (1998) uses the terms LREs and metatalk interchangeably. The important aspect is that during LREs / metatalk, learners attempt to make connections between meaning, forms, and / or functions (Swain, 1998). More specifically, LREs include instances in which learners may (a) question the meaning of a linguistic item; (b) question the correctness of the spelling / pronunciation of a word; (c) question the correctness of a grammatical form; or (d) implicitly or explicitly correct their own or another's usage of a word, form or structure (Swain, 1998). In addition, LREs may include the use of metalinguistic terminology or the articulation of a rule; however, in most cases they do not (Swain, 1998). Swain further explains that it is through LREs that learners notice 
erroneous utterances, and formulate hypotheses, while engaging in other language learning processes such as comprehending.

LREs have received considerable attention in focus-on-form research given that this kind of attention to form "may serve the function of helping students to understand the relationship between meaning, forms, and function in a highly context-sensitive situation" (Swain, 1998, p. 69). Furthermore, these episodes may represent language learning in progress (Swain, 1998; Swain \& Lapkin, 2001).

\section{Dictogloss Tasks and Opinion-Gap Tasks}

Prabhu (1987) identifies three types of tasks - information-gap, reasoning-gap, and opinion-gap. Each task-type requires different levels of cognitive processes. An opinion-gap task involves identifying and articulating a personal preference, feeling, or attitude. An example would be taking part in a discussion about a social issue. A reasoning-gap task involves deriving some new information from given information using practical reasoning. An example would be working out a teacher's timetable based on a set of class timetables. An information-gap task involves the sharing of information to solve a problem, gather information, or make a decision. For example, one student is given an airline timetable with only the arrival times, whereas another student is given the same timetable with only the departure times. The two students will then have to ask each other appropriate questions to complete their respective timetables, so that they both have the planes' departure and arrival times. The dictogloss task is a form of information-gap task (Wajnryb, 1990). Wajnryb further explains that learners are faced with the information-gap when they begin the text reconstruction. This gap exists between their knowledge-to-date (what they remember and what they jot down during the dictation) and the task to be completed. Thus, they have to draw on their knowledge of language use and negotiate with other members of the group to produce a grammatically sound and textually cohesive piece of writing.

Underlying Prabhu's evaluation of the three task-types is his conviction that for tasks to be successful they need to instigate "negotiation" which Prabhu defines as "moving up and down a given line of thought or logic" (Prabhu, 1987, p. 46). In his study, Prabhu (1987) found that reasoning-gap tasks were the most effective in promoting negotiation as some support was provided by the task as well as the teacher. Information-gap tasks, on the other hand, resulted in less negotiation because they did not require students to formulate their own meanings, while opinion-gap tasks proved to be the least successful in promoting negotiation. Prabhu argued that this is so because they were open-ended and students felt insecure in expressing their own feelings and opinions as there is no definite answer or outcome.

Based on Prabhu's argument, it could be deduced that while engaged in an opinion-gap task, students would struggle with the processing of meaning and producing output. This, in turn, could affect the amount of attention given to language use. This is in line with Skehan's limited capacity model, where Skehan argues that when learners reach their attentional limit, they will prioritize processing of meaning over processing of language forms. In the context of the current study, this could mean that learners would focus more on producing intended content, rather than engage in LREs to produce correct forms when conveying meaning.

Recent research on focus-on-form has sought ways to draw learners' attention to linguistic forms without isolating these forms from their meaningful context; dictogloss tasks have sometimes been used in these investigations (e.g., Kowal \& Swain, 1997; Qin, 2008). As one of the leading researchers in the use of tasks in a focus-on-form context, Swain (1998) argues that while engaged in a dictogloss task, L2 learners' attention could be drawn to target forms 
during LREs while the primary focus is meaning. In other words, L2 learners would negotiate both form and meaning while attempting to reconstruct the text given. During the course of completing the task, learners can be prompted (by the teacher or other learners) to notice linguistic problems and engage in discussions of language forms so that meaning becomes clearer (Swain, 1998; Swain \& Lapkin, 2001).

\section{Statement of the Problem}

Many institutions of higher learning in Malaysia use English as the medium of instruction, whether it is for the sciences or social sciences. In light of this, the government has placed greater importance in the mastering of the English language especially among Form 6, pre- $U$, and matriculation students. This is reflected by the inception of an English language proficiency test for the above-mentioned students, named the Malaysian University English Test (MUET). Introduced in 1999, the test consists of four separate papers on the four language skills: listening, speaking, reading, and writing. The results of this test, ranging from Band 1 (lowest) to Band 6 (highest), help determine a candidate's proficiency level for the purpose of entering local universities. Even though the MUET assesses candidates on the four language skills, it has the most impact on the speaking assessment, as the fewer number of candidates, compared to other national school exams, allow for a relatively longer and more intensive test of oral ability (Arshad Abd. Samad, 2004). However, results of this test in the past few years show that candidates are not good users of the language, as they are unable to express their ideas effectively due to "poor control of language" (Dhillon, 2004). This is said to be true for both their writing and speaking components. Thus, there is a need to look into teaching practices in preparing candidates for this test. Grammar errors could perhaps be reduced with the use of sound correction or feedback techniques, and literature has pointed to focus-on-form instruction as one of the most apt options.

\section{Research Questions}

The purpose of the study is to examine the LREs that occurred during meaning-focused lessons using dictogloss and opinion-gap tasks. Specifically, the study addressed the following questions:

a. What are the distributions of outcomes in LREs?

b. What are the grammatical items focused on when learners engage in dictogloss and opinion-gap tasks?

\section{Research Procedures}

Two intact groups from a secondary school were selected. The decision to use intact groups from the same English syllabus as the subjects of the study was made in order to control the length and type of exposure to formal English language instruction during the period of study. The study used a quasi-experimental between-groups research design as it contains comparison between independent groups.

The participants were 40 Form 6 students (18 year-olds) who will be sitting for the MUET at the end of the year. These students were chosen because previous research has shown that focuson-form works best with adult learners who are motivated (Ellis, 2001; Loewen, 2004). The groups of students in Form 6 are generally high academic achievers and on the verge of adulthood. Thus, they are deemed appropriate as participants for the research. Furthermore, the opinion-gap tasks used in the study would correspond to the requirements of their MUET components as these students would have to sit for an oral test of an opinion-gap task-type. 
The researchers developed and adapted pedagogical tasks for use in the two classes. For a period of two weeks, one class was taught using dictogloss tasks, while the other class was taught using opinion-gap tasks. In designing the tasks, we sought to make them as parallel as possible in terms of topic and content (see Appendix). In both classes, students were divided into groups of four. Prior to the lessons, students in the dictogloss group were given explanations about the procedure for the dictogloss task. They were told that they would listen to the reading of a text twice, and that they could write down notes during the second reading. Then they would discuss their notes with members of their group to reconstruct the text. They were also told to make sure that their reconstructed passage, written in one paragraph, was as accurate as possible in terms of content and language use. Meanwhile, the students in the opinion-gap group were told that they would be given five minutes to write short notes based on a given topic, after which they would pool their ideas with other group members and write out their discussion coherently in one paragraph. They were also instructed that each group must make sure that its paragraph was as accurate as possible in terms of language use. The instructions ensured that the task conditions in both groups were as similar as possible. The learners in both the dictogloss and opinion-gap groups had approximately five minutes of individual work - jotting down notes while the teacher read the text (dictogloss) and jotting down ideas based on a given topic (opinion-gap). This was then followed by approximately 20 minutes of group work, where learners in the dictogloss group attempted to reconstruct a text, while learners in the opinion-gap group discussed a given topic.

During the lessons, discussions were audio-recorded. Upon listening to the recording, the LREs were identified, transcribed, and later coded according to their outcomes. According to Swain (1998), the LREs fall into one of three possible outcomes: outcome 1 is when the problem or question was solved correctly; outcome 2 is when LREs were left unresolved or abandoned; outcome 3 is when LREs were resolved incorrectly. Thus the coding categories are as follows:

Outcome 1: Correctly resolved

Outcome 2: Unresolved/abandoned

Outcome 3: Incorrectly resolved

The number of times LREs occurred during classroom discourse was tabulated, presented in frequency counts, and categorized into the three outcomes of LREs. Analysis and interpretations of data would show the similarities and differences in using dictogloss and opinion-gap task types in relation to the types and outcomes of linguistic problems.

\section{Results and Discussion}

The LREs were coded according to their outcomes and linguistic focus. The following are examples of the coding scheme.

Example 1: Dictogloss group

S1: Rubbish can chock rivers.

Outcome: wrongly resolved

S2: Chock ah?

Linguistic item: Vocabulary/Spelling

S1: I think so lah...

S2: How to spell?

S1: C-h-o-c-k 
Example 2: Opinion-gap group

S3: Flood... I think everywhere

S4: The reason for flood occurs in everywhere

S3: Occur everywhere

S4: In everywhere

S5: Everywhere or anywhere?

S3: Everywhere... the reason flood occurs everywhere

S4: The reason flood occurs everywhere
Outcome: correctly resolved

Linguistic item: Preposition (in)

Table 1 below shows the frequency of LREs that occurred in the dictogloss and opinion-gap groups, and their outcomes.

Table 1

Distribution of LREs

\begin{tabular}{|l|c|c|c|c|c|c|}
\hline \multirow{2}{*}{} & \multicolumn{2}{|c|}{ Dictogloss } & \multicolumn{2}{c|}{ Opinion-Gap } & \multicolumn{2}{c|}{ Total } \\
\cline { 2 - 7 } & $n$ & $\%$ & $n$ & $\%$ & $N$ & $\%$ \\
\hline Correctly resolved & 15 & 46.9 & 8 & 47.1 & 23 & 46.9 \\
\hline Unresolved/Abandoned & 10 & 31.3 & 4 & 23.5 & 14 & 28.6 \\
\hline Incorrectly resolved & 7 & 21.9 & 5 & 29.4 & 12 & 24.5 \\
\hline Total & $\mathbf{3 2}$ & & $\mathbf{1 7}$ & & $\mathbf{4 9}$ & \\
\hline
\end{tabular}

Table 1 shows a striking difference in the number of LREs generated by the two tasks. Specifically, the results show that the dictogloss generated almost twice as many LREs as the opinion-gap task (32 vs. 17). This result supports Schmidt's (1990) argument that the more cognitively challenging task (in this case, the opinion-gap task) would "overload" the limited capacity system, thus resulting in less noticing of errors. The higher rate of noticing among learners during the dictogloss task can also be explained by Nassaji's claim that "while coconstructing a passage, the students will come to notice their grammatical strength and weaknesses, and then try to overcome these weaknesses when co-producing the text" (2000, p. 247). This result would imply that teachers need to be aware of cognitive loads inherent in tasks to ensure that noticing of errors is not sidelined.

It is also interesting to note that more than half of the LREs, for both groups, were either unresolved or incorrectly resolved. The result might imply the need to train students to notice erroneous forms and engage in collaborative dialogue to resolve them in LREs. In a study involving 81 matriculation (pre-university) students, Maskanah Mohammad Lotfie (2007) found using reformulation and enhancement techniques useful in encouraging students to notice errors. The learners were also trained to correct these errors, and finally evaluate whether the corrections were accurate or otherwise.

The current study also identified the linguistic items learners focused on during LREs. The table below shows the distribution of grammatical items, vocabulary, and pronunciation problems that were dealt with during LREs. 
Table 2

Distribution of Linguistic Items: Dictogloss Group

\begin{tabular}{|l|c|c|c|c|c|c|c|c|}
\hline & \multicolumn{2}{|c|}{$\begin{array}{c}\text { Correctly } \\
\text { resolved }\end{array}$} & \multicolumn{2}{c|}{$\begin{array}{c}\text { Unresolved/ } \\
\text { Abandoned }\end{array}$} & \multicolumn{2}{c|}{$\begin{array}{c}\text { Incorrectly } \\
\text { resolved }\end{array}$} & \multicolumn{2}{c|}{ Total } \\
\hline & $n$ & $\%$ & $n$ & $\%$ & $n$ & $\%$ & $n$ & $\%$ \\
\hline Tense & 3 & 20.0 & 2 & 20.0 & 1 & 14.3 & 6 & 18.8 \\
\hline S-V Agreement & 5 & 33.3 & 2 & 20.0 & 2 & 28.6 & 9 & 28.1 \\
\hline Adjective & & & & & & & & \\
\hline Adverb & & & 1 & 10.0 & & & 1 & 3.1 \\
\hline Modal & & & 1 & 10.0 & 1 & 14.3 & 2 & 6.3 \\
\hline Preposition & 1 & 6.7 & 1 & 10.0 & 1 & 14.3 & 3 & 9.4 \\
\hline Conditional & & & 1 & 10.0 & & & 1 & 3.1 \\
\hline Vocabulary & 4 & 26.7 & 2 & 20.0 & 2 & 28.6 & 8 & 25.0 \\
\hline Pronunciation & 2 & 13.3 & & & & & 2 & 6.3 \\
\hline Total & $\mathbf{1 5}$ & & $\mathbf{1 0}$ & & $\mathbf{7}$ & & $\mathbf{3 2}$ & \\
\hline
\end{tabular}

Table 3

Distribution of Linguistic Items: Opinion-Gap Group

\begin{tabular}{|l|c|c|c|c|c|c|c|c|}
\hline & \multicolumn{2}{|c|}{$\begin{array}{c}\text { Correctly } \\
\text { resolved }\end{array}$} & \multicolumn{2}{c|}{$\begin{array}{c}\text { Unresolved/ } \\
\text { Abandoned }\end{array}$} & \multicolumn{2}{c|}{$\begin{array}{c}\text { Incorrectly } \\
\text { resolved }\end{array}$} & \multicolumn{2}{c|}{ Total } \\
\hline & $n$ & $\%$ & $n$ & $\%$ & $n$ & $\%$ & $n$ & $\%$ \\
\hline Tense & 2 & 25.0 & 2 & 50.0 & 1 & 20.0 & 5 & 29.4 \\
\hline S-V Agreement & 2 & 25.0 & 1 & 25.0 & 1 & 20.0 & 3 & 17.6 \\
\hline Adjective & & & & & & & & \\
\hline Adverb & & & & & 1 & 20.0 & 1 & 5.9 \\
\hline Modal & & & & & 1 & 20.0 & 1 & 5.9 \\
\hline Preposition & 1 & 12.5 & & & & & 1 & 5.9 \\
\hline Conditional & 1 & 12.5 & & & & & 1 & 5.9 \\
\hline Vocabulary & 1 & 12.5 & 1 & 25.0 & 1 & 20.0 & 4 & 23.5 \\
\hline Pronunciation & 1 & 12.5 & & & & & 1 & 5.9 \\
\hline Total & $\mathbf{8}$ & & $\mathbf{4}$ & & $\mathbf{5}$ & & $\mathbf{1 7}$ & \\
\hline
\end{tabular}

Based on Tables 2 and 3, it can be concluded that, for both groups, the LREs mostly focused on tenses $(18.8 \%$ and $29.4 \%)$, subject-verb agreement $(28.1 \%$ and $17.6 \%)$, and vocabulary $(23.5 \%$ and $25 \%)$. The heavy focus on vocabulary is similar to results found by Williams (1999). In a small-scale study involving eight participants, she found that the focus of the learners' LREs was on lexical meaning rather than syntax. The result would probably indicate the learners' stage of developmental readiness. Learner readiness is closely linked to the learner's existing knowledge systems and processing capacities (Lightbown \& Spada, 1999). This information can be used by teachers to provide tasks and content that would elicit linguistic items in LREs based on the learners' stage of readiness. For example, dictogloss tasks can be manipulated by teachers to elicit target language items using input floods or input enhancement techniques. This means that the texts used are loaded with the target linguistic items; to reconstruct the texts, learners would have to use these grammatical or lexical items. Thus, learners are expected to deal with linguistic problems during the course of reconstructing the passage with making meaning being the driving force.

\section{Conclusions}

The study shows the preliminary results on the facilitative effects of LREs on language learning. Specifically, the study's aim is to investigate the distribution, outcomes, and focus of LREs 
while learners are engaged in two types of tasks. There are, however, some limitations to the research. Given the small number of participants $(n=40)$ involved in the study and the short period of time for data collection, the results cannot be generalized to other contexts.

However, the results do provide some insights into the effects of tasks on LREs and could act as reference for further research to be carried out with a larger and more diverse population of students.

The first research question attempted to determine the distribution of LREs and their outcomes in the two groups. A striking point is that almost double the number of LREs was elicited in the dictogloss group compared to the opinion-gap group. This result appears to support Skehan's (1998) contention that providing support or information (in the form of texts, notes, or pictures) to learners during a task could free up their attention, which could then be directed to other goals (e.g., language accuracy). The results also indicate that more than $50 \%$ of the LREs were unresolved or wrongly resolved. Perhaps this shows that this particular group of learners requires training in noticing linguistic errors and collaboratively correcting these errors, thus producing correct modified output. Some of the techniques that could be used for "noticing training" include reformulation and enhancement techniques. (Enhancement techniques include making target grammar items or linguistic features in the input salient to learners (White, Spada, Lightbown, \& Ranta, 1991). One way is by using various typographical highlighting techniques such as underlining, boldfacing, and italicizing the intended grammar items.) The results could also indicate the need for teacher feedback on language use, perhaps during teacher-fronted pre-task and post-task activities. Further studies could be conducted on types of feedback teachers could give to ensure greater noticing of errors and correct reformulation of errors.

The second research question identified the linguistic items learners focused on during LREs. The results show that tenses, subject-verb agreement, and vocabulary received the most attention from learners. This result might be an indication of learner developmental readiness to notice and understand certain language features. Teachers could then use this information to gear their lessons toward dealing with these linguistic problems through, for instance, the use of input flooding or input enhancement, with texts and tasks that naturally require learners to use intended linguistic items.

This study could help teachers determine types of tasks to use in their classrooms. It has shown that the cognitive loads of tasks, in terms of provision of contextual support, could affect the number of LREs that occur during group-work. Also, learners might have difficulties in noticing errors and collaboratively producing correct modified output. Thus, they might need training in noticing errors. In addition, teachers need to rethink their role during task-based lessons to ensure interlanguage development.

\section{Biodata}

Lilliati Ismail is a Ph.D candidate at Universiti Putra Malaysia. She holds a B.Ed in TESL from the University of Exeter, UK and an M.Ed in TESL from Universiti Malaya, Malaysia. Her areas of interest include second language acquisition and grammar instruction.

Arshad Abd. Samad is a teacher trainer and lecturer at Universiti Putra Malaysia. He received his doctorate from Northern Arizona University and his first two degrees from Indiana University. His interests include grammar instruction, assessment, and second language acquisition. 


\section{References}

Arshad Abd. Samad. (2004). Essentials of language testing for Malaysian teachers. Serdang, Malaysia: Universiti Putra Malaysia Press.

DeKeyser, R. M. (2001). Automaticity and automatization. In P. Robinson (Ed.), Cognition and second language instruction (pp. 125-151). Cambridge, England: Cambridge University Press.

Dhillon, K. K. (2004). Personal encounters and strategies used in teaching the speaking and reading components of the MUET. In M. E. Vethamani (Ed.), Preparing students for the Malaysian University English Test (MUET). Petaling Jaya, Malaysia: Sasbadi.

Ellis, R. (2001). Introduction: Investigating form-focused instruction [Special issue]. Language Learning, 51(1), 1-46. http://dx.doi.org/10.1111/j.1467-1770.2001.tb00013.x

Ellis, R., Basturkmen, H., \& Loewen, S. (2001). Learner uptake in communicative ESL lessons. Language Learning, 51(2), 281-318. http://dx.doi.org/10.1111/1467-9922.00156

Ellis, R., Basturkmen, H., \& Loewen, S. (2002). Doing focus-on-form. System, 30(4), 419-432. http://dx.doi.org/10.1016/S0346-251X(02)00047-7

Ishikawa, T. (2006). The effect of task complexity and language proficiency on task-based language performance. The Journal of Asia TEFL, 3(4), 193-225.

Kowal, M., \& Swain, M. (1997). From semantic to syntactic processing: How can we promote metalinguistic awareness in the French immersion classroom? In R. K. Johnson \& M. Swain (Eds.), Immersion education: International perspectives (pp. 284-309). Cambridge, England: Cambridge University Press.

Krashen, S. (1985). The input hypothesis: Issues and implications. New York, NY: Longman.

Leeman, J. (2007). Feedback in L2 learning: Responding to errors during practice. In R. M. DeKeyser (Ed.), Practice in a second language: Perspectives from linguistics and psychology (pp. 111-137). Cambridge, England: Cambridge University Press.

Lenneberg, E. H. (1967). Biological foundations of language. New York, NY: Wiley.

Lightbown, P., \& Spada, N. (1990). Focus-on-form and corrective feedback in communicative language teaching: Effects on second language learning. Studies in Second Language Acquisition, 12(4), 429-448. http://dx.doi.org/10.1017/S0272263100009517

Loewen, S. (2004). Uptake in incidental focus on form in meaning-focused ESL lessons. Language Learning, 54(1), 153-188. http://dx.doi.org/10.1111/j.14679922.2004.00251.x

Long, M. (1985). Input and second acquisition theory. In S. Gass \& C. Madden (Eds.), Input in second language acquisition. Rowley, MA: Newbury House.

Long, M. (1991). Focus on form: A design feature in language teaching methodology. In K. de Bot, R. Ginsberg, \& C. Kramsch (Eds.), Foreign language research in cross-cultural perspective. Amsterdam, Netherlands: John Benjamins.

Long, M. (1996). The role of linguistic environment in second language acquisition. In W. C. Ritchie \& T. K. Bhatia (Eds.), Handbook of second language acquisition. New York, NY: Academic Press.

Long, M., \& Robinson, P. (1998). Focus on form: Theory, research and practice. In C. Doughty \& J. Williams (Eds.), Focus on form in classroom second language acquisition. Cambridge, England: Cambridge University Press.

Maskanah Mohammad Lotfie (2007). The effects of noticing training on Malay ESL learners' use of past time forms in writing. Unpublished doctoral degree dissertation. Universiti Putra Malaysia.

Nassaji, H. (2000). Towards integrating form-focused instruction and communicative interaction in the second language classroom: Some pedagogical possibilities [Exchange article]. The Modern Language Journal, 84(2), 241-250. http://dx.doi.org/10.1111/0026-7902.00065 
Norris, J., \& Ortega, L. (2000). Effectiveness of L2 instruction: A research synthesis and quantitative meta-analysis. Language Learning, 50(3), 417-528. http://dx.doi.org/10.1111/0023-8333.00136

Pandian, A., \& Lee, K. S. (2001). Updated practical guide to MUET: Malaysian University English Test. Serdang, Malaysia: Universiti Putra Malaysia Press.

Pica, T. (1994). Research on negotiation. What does it reveal about second-language learning conditions, processes, and outcomes? Language Learning, 44(3), 493-527. http://dx.doi.org/10.1111/j.1467-1770.1994.tb01115.x

Prabhu, N. S. (1987). Second language pedagogy. Oxford, England: Oxford University Press.

Qin, J. (2008). The effect of processing instruction and dictogloss tasks on acquisition of the English passive voice. Language Learning, 12(1), 61-82. http://dx.doi.org/10.1177/1362168807084494

Robinson, P. (2001). Task complexity, cognitive resources, and syllabus design: A triadic framework for examining task influences on SLA. In P. Robinson (Ed.), Cognition and second language instruction (pp. 287-318). Cambridge, England: Cambridge University Press.

Schmidt, R. (1990). The role of consciousness in second language learning. Applied Linguistics, 11(2), 129-158. http://dx.doi.org/10.1093/applin/11.2.129

Skehan, P. (1998). A cognitive approach to language learning. Oxford, England: Oxford University Press.

Skehan, P., \& Foster, P. (2001). Cognition and tasks. In P. Robinson (Ed.), Cognition and second language instruction. Cambridge: Cambridge University Press.

Swain, M. (1995) Three functions of output in second language learning. In G. Cook \& B. Seidlhofer (Eds.), Principle and practice in applied linguistics: Studies in honor of H.G. Widdowson (pp. 125-144). Oxford, England: Oxford University Press.

Swain, M. (1998). Focus on form through conscious reflection. In C. Doughty \& J. Williams (Eds.), Focus on form in classroom second language acquisition. Cambridge, England: Cambridge University Press.

Swain, M., \& Lapkin, S. (2001). Focus on form through collaborative dialogue: Exploring task effects. In M. Bygate, P. Skehan \& M. Swain (Eds.), Researching pedagogic tasks: Second language learning, teaching and testing. London, England: Longman.

Van Patten, B. (1990). Attending to form and content in the input: An experiment in consciousness. Studies in Second Language Acquisition, 12(3), 287-301. http://dx.doi.org/10.1017/S0272263100009177

Wajnryb, R. (1990). Grammar dictation. Oxford, England: Oxford University Press.

White, L., Spada, N., Lightbown, P., \& Ranta, L. (1991). Input enhancement and L2 question formation. Applied Linguistics, 12(4), 416-432. http://dx.doi.org/10.1093/applin/12.4.416

Williams, J. (1999). Learner-generated attention to form. Language Learning, 49(4), 583-625. http://dx.doi.org/10.1111/0023-8333.00103 


\section{Appendix \\ Sample Tasks}

\section{Dictogloss}

Instructions: You will be listening to a text read twice at normal reading speed. The first time the text is read, you should just listen and not write anything down. As you listen for the second time, write down key words or short-notes. Then, get into your groups and try to reconstruct the text in one paragraph. Your text should be as accurate as possible in terms of content and language use.

Time for task: 20 minutes

Text:

1. Savings enables one to deal with emergencies.

2. An emergency can be a sickness, an accident or any unfortunate situation that requires the spending of large sums of money.

3. Life is full of uncertainties.

4. One minute you may be strong and healthy and the next you may be sick and weakly.

5. One moment life may be smooth sailing and the next it may turn rough and stormy.

6. You may have an accident, you may lose your job or your house may be burnt down in a fire.

7. Only if you have savings can you deal with contingencies for the sums of money required are large.

(Text adapted from Pandian and Lee, 2001)

\section{Opinion-Gap}

Instructions: In your groups, discuss the topic below. Then, write out your group's discussion in one paragraph.

Topic: The importance of saving money to deal with emergencies.

Time for task: 20 minutes 